\title{
Change in the Agrochemical Properties of Soils and the Productivity of the Wheel Under the Influence of Electromagnetic Waves
}

\author{
Yuldashev Gulom \\ Professor of Fergana State University, Fergana, Uzbekistan \\ Corresponding author email: g.yuldashev@umail.uz. \\ Marupov Azizxon Abbosxonovich \\ Assistant of Fergana Polytechnic Institute, Fergana, Uzbekistan \\ Email: a.marupov@ferpi.uz.
}

\begin{abstract}
In recent years, in the world, the anthropogenic impact on the soil, entailing various changes in its properties, is becoming more severe. Especially it is necessary to note the lands located on the boundaries of the protection zones of linear objects. This article studies the agrochemistry of soils that are under zones and linear protection objects and the effect of electric waves on wheat productivity. Overhead power lines have a negative impact on the environment, in particular on its ecological, social, and economic systems due to the high intensity of the electromagnetic field around the lead wires. High-voltage power lines do not significantly affect the content of humus and nutrients.
\end{abstract}

Keywords---agriculture, agrochemical, geographic information systems, power lines, soil

\section{Introduction}

The world pays special attention to the implementation of scientific research on the use of modern geoinformation technologies and remote sensing methods for the study, assessment, and monitoring of lands for agricultural purposes. In view of theory, it seems relevant to study the composition, properties, and monitoring of soils located within the boundaries of protected zones and linear objects using modern geoinformation technologies. For this, it is necessary to note the important role of high-voltage power lines on the properties and productivity of crops (Corwin \& Lesch, 2005; McLaughlin \& Mineau, 1995).

Uzbekistan contains an open list of zones with special conditions for the use of territories, which are established in order to protect the environment or an object from negative external influences. In relation to them, it is legitimate to use the general term "security zones". In terms of its content, it boils down to prohibitions on the implementation of certain types of activities and to the obligations to fulfill the established ones (Neverova, 2011). At the same time, security zones are located on land plots of many categories and types of permitted use, owned, owned, and used by individuals and legal entities. At the same time, only the total area of land located within the boundaries of protected zones (power lines, gas pipelines, transport, etc.) is about 1/5 of the total land-use area. One of the objectives of the study is an analysis of the agrochemical properties of soils in protective zones of linear objects and the impact on the yield of vegetation (Karhu et al., 2011; Brussaard et al., 2007).

\section{Objectives}

The object is soil located on land plots security zones of high-voltage electric lines (power lines), which form electromagnetic waves Fergana and Yazyavan regions (Yuldashev \& Marupov, 2019). The climate of the Fergana and Yazyavan regions is suitable for obtaining a high-quality wheat harvest. Winter is mild, sometimes harsh. The average January temperature is $-3.2^{\circ} \mathrm{C}$ (Fergana), the absolute minimum is $-25^{\circ} \mathrm{C}$. The snow cover is short-lived. 
On some winter days, the weather is warm. Hot summer (Thapa \& Murayama, 2008; Rehakova et al., 2004). The average July temperature is $+28{ }^{\circ} \mathrm{C}$, the maximum is $+40.4{ }^{\circ} \mathrm{C}$. Average long-term meteorological indicatorsFergana and Yazyavan regions are represented in table-1. The sum of effective temperatures in the regions of Fergana and Yazyavan is $2430{ }^{\circ} \mathrm{C}$, and in Yazyavan it is $2459{ }^{\circ} \mathrm{C}$. The duration of the growing season with temperatures above $11^{\circ} \mathrm{C}$ is 223 days. From the given data of the table, it can be seen that the average annual air temperature both in the Fergana region and in the Yazyavan region is not the same and amounts to $15.0-16.2^{\circ} \mathrm{C}$.

Table 1

Average long-term meteorological indicators

\begin{tabular}{|c|c|c|c|c|c|c|c|c|c|c|c|c|c|}
\hline \multirow{2}{*}{ Stations } & \multicolumn{12}{|c|}{ Months } & \multirow{2}{*}{$\begin{array}{l}\text { Average } \\
\text { annual }\end{array}$} \\
\hline & I & II & III & IV & $\mathrm{V}$ & VI & VII & VIII & IX & $\mathrm{X}$ & $\mathrm{XI}$ & XII & \\
\hline \multicolumn{14}{|c|}{ Temperature, air, ${ }^{0} \mathrm{C}$} \\
\hline $\begin{array}{l}\text { Fergana } \\
\text { region }\end{array}$ & -2.3 & 1,2 & 8.1 & 16.1 & 21.2 & 25.2 & 26.2 & 24.4 & 19.5 & 13.1 & 5.4 & 0.3 & 13.2 \\
\hline Yazyavan & -2.2 & 0.9 & 7.6 & 15.4 & 20.5 & 25.1 & 25.9 & 25.1 & 19.6 & 12.6 & 8.5 & 0.3 & 13.3 \\
\hline \multicolumn{14}{|c|}{ Precipitation, $\mathrm{mm}$} \\
\hline $\begin{array}{l}\text { Fergana } \\
\text { region }\end{array}$ & 14 & 12 & 18 & 13 & 12 & 8 & 4 & 3 & 2 & 9 & 14 & 12 & 121 \\
\hline Yazyavan & 18 & 21 & 29 & 21 & 16 & 10 & 4 & 2 & 3 & 12 & 21 & 18 & 165 \\
\hline \multicolumn{14}{|c|}{ Relative humidity, $\%$} \\
\hline $\begin{array}{l}\text { Fergana } \\
\text { region }\end{array}$ & 83 & 83 & 72 & 62 & 53 & 46 & 51 & 57 & 62 & 69 & 76 & 83 & 66.4 \\
\hline Yazyavan & 82 & 81 & 71 & 58 & 53 & 45 & 44 & 52 & 57 & 65 & 76 & 82 & 63.8 \\
\hline \multicolumn{14}{|c|}{ Soil temperature ${ }^{\circ} \mathrm{C}$} \\
\hline $\begin{array}{l}\text { Fergana } \\
\text { region }\end{array}$ & -3 & 1 & 9 & 12 & 26 & 32 & 33 & 30 & 22 & 13 & 4 & 1 & 15.0 \\
\hline Yazyavan & -2 & 1 & 8 & 13 & 27 & 31 & 36 & 34 & 25 & 14 & 5 & 2 & 16.2 \\
\hline
\end{tabular}

As for precipitation, there is a big difference between the desert and gray earth zones (Abdullayev \& Marupov, 2020; Marupov \& Axmedov, 2020). If in Yazyavan there is an average of $121 \mathrm{~mm}$ of precipitation, in the Fergana region $165 \mathrm{~mm}$ is almost one and a half more. The relative humidity is practically the same at 64\%; The soil temperature is also practically the same both in the meadow saz soils of Yazyavan and in the sierozem of Fergana and is $15-16{ }^{\circ} \mathrm{C}$. Newly irrigated meadow soils of the irrigation-saz moistening regime usually occupy well-planned, somewhat lowered territories, and they are formed mostly in the desert zone of central Fergana (Basso et al., 2000; Bastian et al., 2002). The humus content in the arable horizon of these meadow soils ranges from 0.82 to $1.15 \%$ (Figure 1 ).

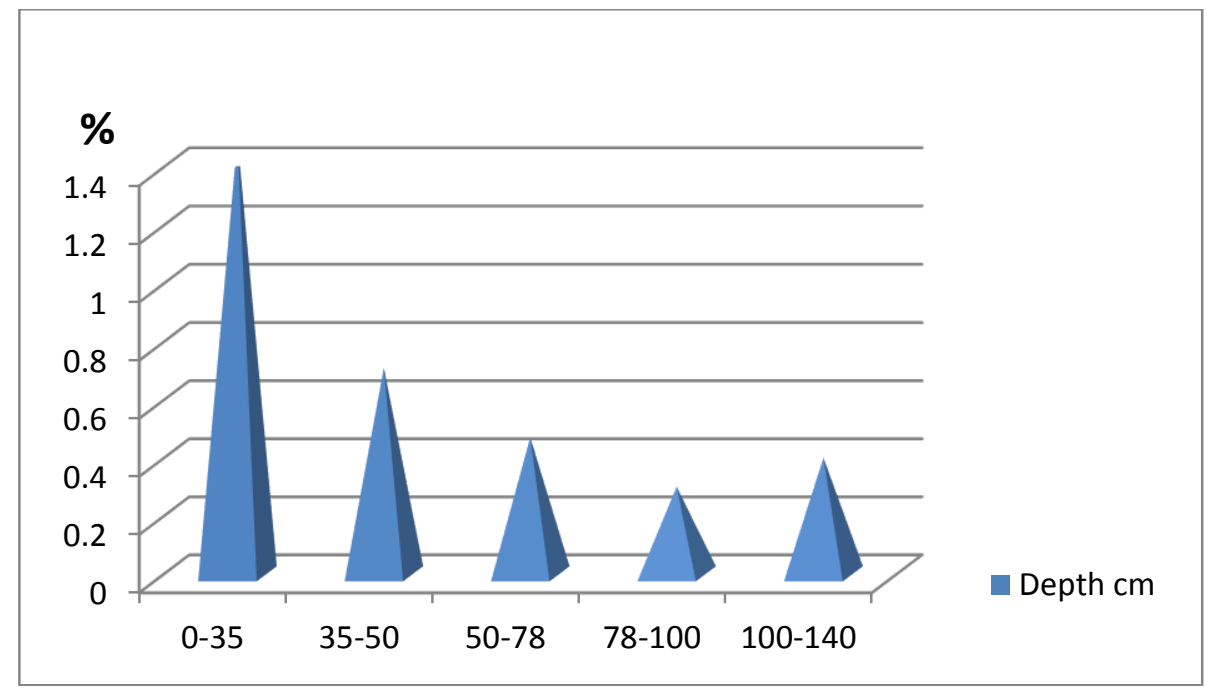

Figure 1. Humus content in the profile of newly irrigated meadow saz soils in Central Fergana (Yazyavan region) 
The nitrogen content depends on the amount of humus and ranges from 0.033 to $0.035 \%$. Newly irrigated meadow saz soils are poorly provided with mobile forms of phosphorus. At the same time, fluctuations in its content vary from 13 to $19 \mathrm{mg} / \mathrm{kg}$ of soil, which is associated, first of all, with the uneven application of phosphorus fertilizers and the state of the soil. The soils are insufficiently and moderately supplied with mobile forms of potassium (160-321 $\mathrm{mg} / \mathrm{kg}$ of soil) (Saravanadurai \& Manimehalai, 2016; Sadguna et al., 2017).

The object of the study is irrigated typical, light, serezem, piedmont gentle plains, adjacent to the merged fan and upper river terraces, folded loesses, loess-like loams and skeletal-fine earthy proluvium and deluvium on the territory of the Fergana region (Marupov, 2020). Soil: Water-irrigated serozem, typical cultivated, medium-loamy on medium and light loam, with 1-2 m, in places with 0.5-0.8 m, underlain by pebbles, newly irrigated serozem light, weakly cultivated, skeletal-fine earth, with 0.3-0.5 m, less often from $0.1 \mathrm{~m}$ underlain by pebbles, etc. (Figure 2)

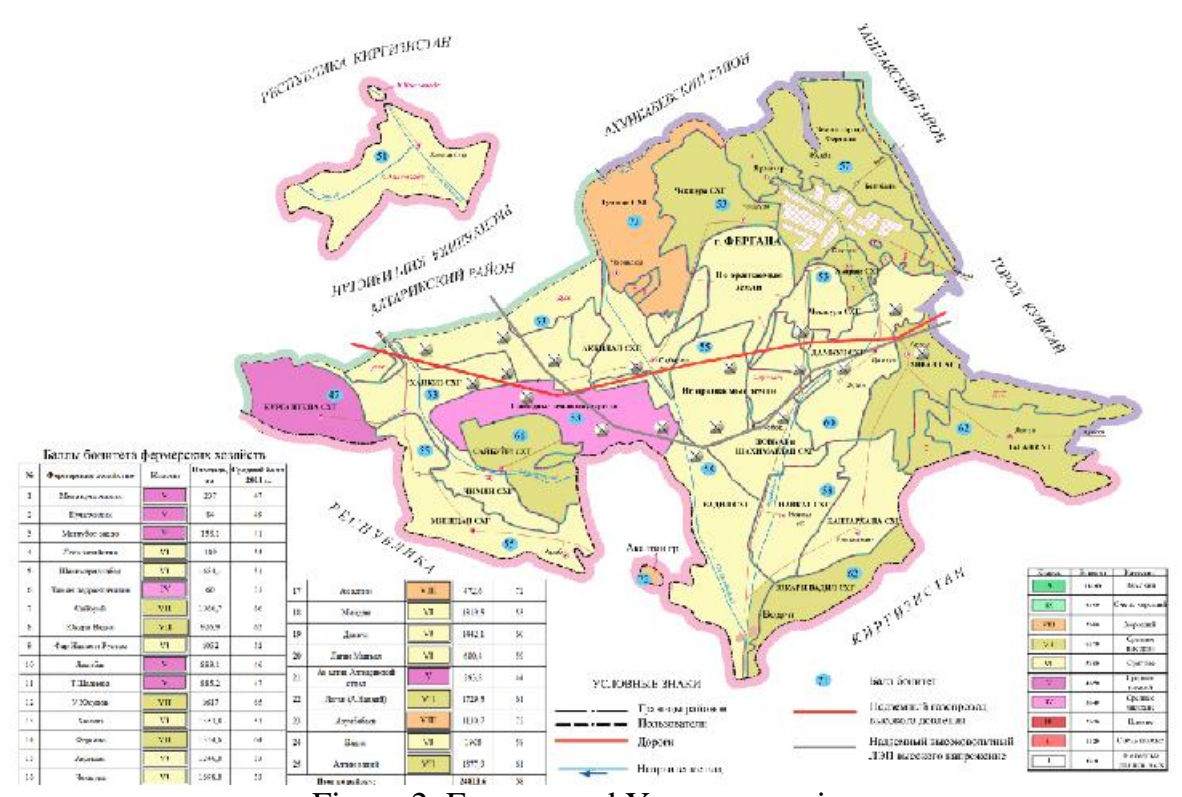

Figure 2. Fergana and Yazyavan regions

On the territory of the Yazyavan region, on flat plains composed of layered alluvial-molten sediments, soils are grown, meadow saz, salted (Figure 3).

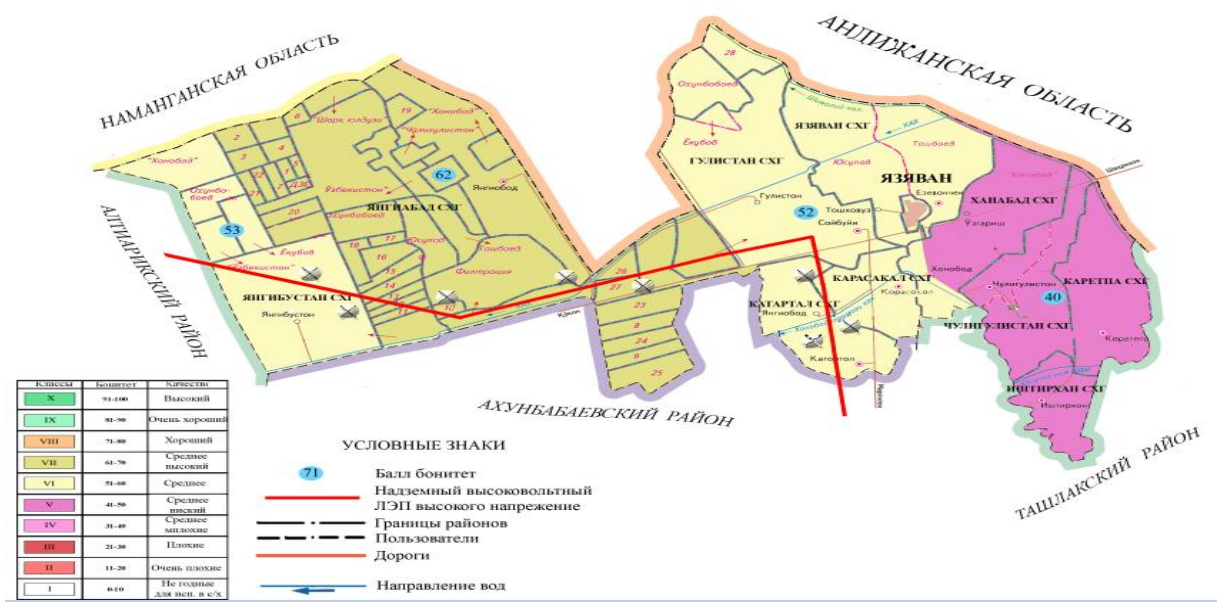

Figure 3. Fergana and Yazyavan regions

Also, in Figures 2-3, the trajectories of the electric transmission line are shown and the sections for sampling soils in the Fergana and Yazyavan regions are marked. 


\section{Statistical design}

The following analyzes were carried out in the selected soil samples:

a) humus according to the Tyurin method;

b) gross nitrogen and phosphorus, potassium in one sample according to the method of Maltseva, Gritsenko;

c) mobile phosphorus according to Machigin;

d) mobile potassium from $1 \%$ ammonium extract according to Protasov;

e) water-soluble salts by the method of water extracts;

f) the mechanical composition of the soil by the pipette method using sodium hexametaphosphate;

Table 2 shows the results of changes in humus content in soils according to Ferganagiprozem and the author. Changes in growth, development, and weight of 1000 wheat seeds under the influence of irrigation with saline waters (Numanovich \& Abbosxonovich, 2020).

Table 2

Change in irrigated areas with humus content

\begin{tabular}{|c|c|c|c|c|c|c|}
\hline \multirow{2}{*}{ No. } & \multirow{2}{*}{ Farm } & \multicolumn{5}{|c|}{ Humus, $\%$} \\
\hline & & up to $1 \%$ & $1.1-2 \%$ & $2.1-3 \%$ & $>3 \%$ & Total, ha \\
\hline 1 & Meva kchatchilik & & thirty & 207 & & 237 \\
\hline 2 & Kchatchilik & 36 & 48 & & & 84 \\
\hline 3 & Matlubot Savdo & & 158 & & & 158 \\
\hline 4 & Y̌rmon khy̆zhaligi & & 109 & & & 109 \\
\hline 5 & Shohimardonobod & 827 & 745 & 113 & & 1685 \\
\hline 6 & Chimeon parrandachilik & 60 & & & & 60 \\
\hline 7 & Soibuyi & 946 & 120 & & & 1066 \\
\hline 8 & Үuқоri drove * & 620 & 307 & & & 927 \\
\hline 9 & Far Navkent Rustam & 452 & 473 & 108 & & 1033 \\
\hline 10 & Yangiboғ * & 280 & 604 & & & 884 \\
\hline 11 & T. Shodieva * & & 830 & 56 & & 886 \\
\hline 12 & U. Yusupov* & 550 & 1067 & & & 1617 \\
\hline 13 & Нопқіz * & 860 & 494 & & & 1354 \\
\hline 14 & Farғona & 155 & 870 & 325 & 4 & 1354 \\
\hline 15 & Оқbilol * & 1110 & 147 & & & 1457 \\
\hline 16 & Chekshura & 294 & 1255 & 151 & & 1700 \\
\hline 17 & Oh oltin & 238 & 234 & & & 472 \\
\hline 18 & Mindon * & 790 & 250 & 279 & & 1319 \\
\hline 19 & Damkul & 688 & 754 & & & 1442 \\
\hline 20 & Logon Mashal & 104 & 576 & & & 680 \\
\hline 21 & Оқ oltin, Oltiariқ by̆limi & 294 & & & & 294 \\
\hline 22 & Logon (A. Navoi) & 817 & 890 & 22 & & 1729 \\
\hline 23 & Ochunboboev & 708 & 422 & & & 1130 \\
\hline 24 & Drove * & 801 & 1041 & 126 & & 1968 \\
\hline \multirow[t]{2}{*}{25} & Oltin vodiy * & 632 & 440 & 306 & & 1378 \\
\hline & Total: & 11282 & 11829 & 1698 & 4 & 24813 \\
\hline
\end{tabular}

* author data, 2020-2021

As can be seen from the table, the area of soils with different humus contents does not change significantly for almost 10 years, small changes are observed in areas with humus contents of $1.1-2 \%$, mainly due to the humus content of up to $1 \%$, which is associated with constant improvements in the state of culture of soils (Marupov et al., 2021). Phenological observations (table-3) showed that the distance from the power line increases the growth and development of wheat. 
Table 3

Growth, development of wheat under the influence of electromagnetic waves

\begin{tabular}{|c|c|c|c|c|c|c|c|}
\hline \multirow[b]{2}{*}{$\begin{array}{l}\text { Key area } \\
\text { number }\end{array}$} & \multirow{2}{*}{$\begin{array}{l}\text { Distance } \\
\text { from power } \\
\text { lines, } m\end{array}$} & \multirow[b]{2}{*}{ Repetition } & \multicolumn{4}{|c|}{ Plant growth, sm } & \multirow{2}{*}{$\begin{array}{l}\text { Weight of } \\
1000 \\
\text { seeds, g. }\end{array}$} \\
\hline & & & $\begin{array}{l}\text { Tube- } \\
\text { vanie }\end{array}$ & $\begin{array}{l}\text { Koloso- } \\
\text { vanie }\end{array}$ & $\begin{array}{l}\text { Milky-wax } \\
\text { ripeness }\end{array}$ & Maturity & \\
\hline \multicolumn{8}{|c|}{ Irrigated typical gray soil (to the left of the power line) } \\
\hline 1 & \multirow{3}{*}{0} & 1 & 83.1 & 95.0 & 98.5 & 110.1 & 43.9 \\
\hline & & 2 & 94.6 & 95.3 & 98.1 & 111.3 & 44.3 \\
\hline & & 3 & 80.6 & 101.0 & 106.8 & 110.8 & 48.4 \\
\hline the average & & - & 86.1 & 97.1 & 101.1 & 110.7 & 45.5 \\
\hline \multirow[t]{3}{*}{2} & \multirow{4}{*}{ thirty } & 1 & 84.4 & 100.1 & 99.5 & 111.1 & 44.9 \\
\hline & & 2 & 87.3 & 100.3 & 99.4 & 110.3 & 45.6 \\
\hline & & 3 & 83.6 & 105.1 & 109.4 & 115.4 & 50.1 \\
\hline the average & & - & 85.1 & 101.8 & 102.8 & 112.3 & 46.9 \\
\hline \multirow[t]{3}{*}{3} & \multirow{4}{*}{60} & 1 & 90.3 & 109.6 & 101.5 & 115.5 & 45.5 \\
\hline & & 2 & 95.5 & 105.5 & 105.4 & 110.2 & 45.6 \\
\hline & & 3 & 83.3 & 106.6 & 108.5 & 120.4 & 52.8 \\
\hline \multirow[t]{2}{*}{ the average } & & - & 89.7 & 107.2 & 105.1 & 115.4 & 48.0 \\
\hline & \multicolumn{6}{|c|}{ Irrigated typical gray soil (to the right of the power line) } & \\
\hline \multirow[t]{3}{*}{$1 \mathrm{a}$} & \multirow{4}{*}{0} & 1 & 83.1 & 95.0 & 98.5 & 110.1 & 43.9 \\
\hline & & 2 & 94.6 & 95.3 & 98.1 & 111.3 & 44.3 \\
\hline & & 3 & 80.5 & 101.3 & 106.8 & 110.8 & 48.4 \\
\hline the average & & - & 86.1 & 97.2 & 101.1 & 110.7 & 45.5 \\
\hline \multirow[t]{3}{*}{$2 \mathrm{a}$} & \multirow{4}{*}{ thirty } & 1 & 86.6 & 110.1 & 115.1 & 120.5 & 49.1 \\
\hline & & 2 & 91.8 & 111.4 & 120.5 & 119.8 & 44.8 \\
\hline & & 3 & 93.4 & 98.5 & 115.6 & 115.6 & 47.4 \\
\hline the average & & - & 90.6 & 106.7 & 117.1 & 118.6 & 47.1 \\
\hline \multirow[t]{3}{*}{$3 \mathrm{a}$} & \multirow{4}{*}{60} & 1 & 91.4 & 115.6 & 115.6 & 121.6 & 51.1 \\
\hline & & 2 & 98.1 & 111.5 & 120.4 & 125.6 & 46.8 \\
\hline & & 3 & 101.6 & 101.5 & 120.5 & 120.6 & 48.1 \\
\hline the average & & - & 97.0 & 109.5 & 118.8 & 122.6 & 48.7 \\
\hline
\end{tabular}

The greatest growth is observed at a distance of $60 \mathrm{~m}$ from the power transmission line in the phase of maturity and averages 115.4 seeds (Mamanazarovna \& Abbosxonovich, 2021). Changes in the growth and development of wheat led to changes in yields, which are presented in table 4.

Table 4

Change in wheat yield

\begin{tabular}{|c|c|c|c|c|c|c|}
\hline \multirow{2}{*}{ Key area number } & \multirow{2}{*}{$\begin{array}{l}\text { Distance from } \\
\text { power lines, m }\end{array}$} & \multirow{2}{*}{ Repetition } & \multicolumn{4}{|c|}{ Productivity, ha } \\
\hline & & & corn & straw & corn & straw \\
\hline & \multicolumn{3}{|c|}{ With the right from the power line, 2019} & \multicolumn{3}{|c|}{$2020 \mathrm{y}}$. \\
\hline & \multirow{3}{*}{0} & 1 & 45.2 & 69.0 & 50.2 & 73.2 \\
\hline \multirow[t]{2}{*}{1} & & 2 & 44.8 & 66.8 & 49.3 & 70.2 \\
\hline & & 3 & 46.2 & 68.8 & 50.8 & 72.5 \\
\hline \multirow[t]{2}{*}{ the average } & \multirow{4}{*}{ thirty } & - & 45.4 & 68.2 & 50.1 & 72.0 \\
\hline & & 1 & 48.8 & 71.3 & 53.1 & 76.9 \\
\hline \multirow[t]{2}{*}{2} & & 2 & 47.4 & 70.5 & 52.2 & 74.2 \\
\hline & & 3 & 48.3 & 73.1 & 53.4 & 76.9 \\
\hline \multirow[t]{2}{*}{ the average } & & - & 48.2 & 71.6 & 52.9 & 76.0 \\
\hline & & 1 & 52.1 & 72.7 & 57.2 & 79.7 \\
\hline \multirow[t]{2}{*}{3} & 60 & 2 & 51.2 & 73.5 & 56.8 & 77.8 \\
\hline & & 3 & 49.8 & 74.8 & 58.7 & 78.5 \\
\hline the average & & - & 51.03 & 73,7 & 57.6 & 78.7 \\
\hline
\end{tabular}




\begin{tabular}{|c|c|c|c|c|c|c|}
\hline & \multicolumn{3}{|c|}{ To the left of the power line, 2019} & \multicolumn{3}{|c|}{$2020 \mathrm{y}}$. \\
\hline & & 1 & 45.2 & 69.0 & 50.2 & 73.2 \\
\hline \multirow[t]{2}{*}{ 1a } & 0 & 2 & 44.8 & 66.8 & 49.3 & 70.2 \\
\hline & & 3 & 46.2 & 68.8 & 50.8 & 72.5 \\
\hline \multirow[t]{2}{*}{ the average } & & - & 45.4 & 68.2 & 50.1 & 72.0 \\
\hline & & 1 & 50.8 & 73.3 & 54.1 & 80.6 \\
\hline \multirow[t]{2}{*}{$2 \mathrm{a}$} & thirty & 2 & 51.4 & 72.8 & 53.7 & 77.5 \\
\hline & & 3 & 50.4 & 73.8 & 54.6 & 80.4 \\
\hline \multirow[t]{2}{*}{ the average } & & - & 50.9 & 73.3 & 54.1 & 79.5 \\
\hline & & 1 & 54.1 & 74.5 & 60.2 & 81.9 \\
\hline \multirow[t]{2}{*}{$3 \mathrm{a}$} & 60 & 2 & 52.8 & 76.1 & 61.1 & 79.6 \\
\hline & & 3 & 50.5 & 75.5 & 59.8 & 81.9 \\
\hline the average & & - & 52.5 & 75.4 & 60.4 & 81.1 \\
\hline
\end{tabular}

From which it can be seen that the highest yield corresponds to key areas 3 and 3a, which are located at a distance of $60 \mathrm{~m}$. Both to the left and the right of the power line (Turdaliev et al., 2021).

\section{Results}

Overhead power lines have a negative impact on the environment, in particular on its ecological, social, and economic systems due to the high intensity of the electromagnetic field around the lead wires. High-voltage power lines do not significantly affect the content of humus and nutrients (Lagacherie \& McBratney, 2006; Soane \& Van Ouwerkerk, 1994). Electromagnetic fields of power transmission lines negatively affect the growth, development, and yield of wheat, where directly under the power transmission line (zero physical point) it decreases by 7-10 c / ha.

\section{References}

Abdullayev, I. N., \& Marupov, A. A. (2020). The Analysis Of Lands In Security Zones Of High-Voltage Power Lines (Power Line) On The Example Of The Fergana Region.

Basso, F., Bove, E., Dumontet, S., Ferrara, A., Pisante, M., Quaranta, G., \& Taberner, M. (2000). Evaluating environmental sensitivity at the basin scale through the use of geographic information systems and remotely sensed data: an example covering the Agri basin (Southern Italy). Catena, 40(1), 19-35. https://doi.org/10.1016/S0341-8162(99)00062-4

Bastian, C. T., McLeod, D. M., Germino, M. J., Reiners, W. A., \& Blasko, B. J. (2002). Environmental amenities and agricultural land values: a hedonic model using geographic information systems data. Ecological economics, 40(3), 337-349. https://doi.org/10.1016/S0921-8009(01)00278-6

Brussaard, L., De Ruiter, P. C., \& Brown, G. G. (2007). Soil biodiversity for agricultural sustainability. Agriculture, ecosystems \& environment, 121(3), 233-244. https://doi.org/10.1016/j.agee.2006.12.013

Corwin, D. L., \& Lesch, S. M. (2005). Apparent soil electrical conductivity measurements in agriculture. Computers and electronics in agriculture, 46(1-3), 11-43. https://doi.org/10.1016/j.compag.2004.10.005

Karhu, K., Mattila, T., Bergström, I., \& Regina, K. (2011). Biochar addition to agricultural soil increased CH4 uptake and water holding capacity-Results from a short-term pilot field study. Agriculture, ecosystems \& environment, 140(1-2), 309-313. https://doi.org/10.1016/j.agee.2010.12.005

Lagacherie, P., \& McBratney, A. B. (2006). Spatial soil information systems and spatial soil inference systems: perspectives for digital soil mapping. Developments in soil science, 31, 3-22. https://doi.org/10.1016/S01662481(06)31001-X

Mamanazarovna, E. M., \& Abbosxonovich, M. A. (2021). Analysis of Agricultural Soils Designation of Different Linear Protected Zones using GIS Technology. CENTRAL ASIAN JOURNAL OF THEORETICAL \& APPLIED SCIENCES, 2(11), 188-192.

Marupov, A. (2020). Improvement of innovative mechanism for rational use of natural and land resources in Uzbekistan. Collection of scientific works $\Lambda^{\prime} O \Gamma \Sigma, 100-101$.

Marupov, A., \& Axmedov, B. (2020). General Characteristics Of Zones With Special Conditions For Using The Territory Of The City Of Fergana. Collection of scientific works 1'OГOL, 7-10.

Marupov, A., Turamuratova, G., Rasulova, M., \& Marupov, U. A. (2021). Soil Solarization and Sideration in Cotton Wilt Control in Uzbekistan. Annals of the Romanian Society for Cell Biology, 3259-3270. 
McLaughlin, A., \& Mineau, P. (1995). The impact of agricultural practices on biodiversity. Agriculture, Ecosystems \& Environment, 55(3), 201-212. https://doi.org/10.1016/0167-8809(95)00609-V

Neverova, O. P. (2011). Shherbakov IV The total catalase activity of soils and CCS in the National Park «Smolenskoye Lake District». Agrarian Bulletin of the Urals, (2), 81.

Numanovich, A. I., \& Abbosxonovich, M. A. (2020). About The Special Regime Of Use And Standards Of Land Plots And Their Buffer Zones Located In Borders Of Roadside Strips Of Highways Of The Ferghana Region Of The Republic Of Uzbekistan. The American Journal of Engineering and Technology, 2(09), 77-81.

Rehakova, M., Čuvanová, S., Dzivak, M., Rimár, J., \& Gaval'Ova, Z. (2004). Agricultural and agrochemical uses of natural zeolite of the clinoptilolite type. Current Opinion in Solid State and Materials Science, 8(6), 397-404. https://doi.org/10.1016/j.cossms.2005.04.004

Sadguna, D. N., Sulistiawati, N. P. A., \& Astiari, N. K. A. (2017). Contributions of household income of farmers as palm crafts outside agriculture sector. International Research Journal of Engineering, IT \& Scientific Research, 3(5), 86-96. Retrieved from https://sloap.org/journals/index.php/irjeis/article/view/579

Saravanadurai, A., \& Manimehalai, N. (2016). Primary agricultural credit societies in India. International Research Journal of Engineering, IT \& Scientific Research,2(7), 51-61. Retrieved from https://sloap.org/journals/index.php/irjeis/article/view/498

Soane, B. D., \& Van Ouwerkerk, C. (1994). Soil compaction problems in world agriculture. In Developments in agricultural engineering (Vol. 11, pp. 1-21). Elsevier. https://doi.org/10.1016/B978-0-444-88286-8.50009-X

Thapa, R. B., \& Murayama, Y. (2008). Land evaluation for peri-urban agriculture using analytical hierarchical process and geographic information system techniques: A case study of Hanoi. Land use policy, 25(2), 225-239. https://doi.org/10.1016/j.landusepol.2007.06.004

Turdaliev, A., Yuldashev, G., Askarov, K., \& Abakumov, E. (2021). Chemical and biogeochemical features of desert soils of the central Fergana. Agriculture (Pol'nohospodárstvo), 67(1), 16-28.

Yuldashev, G., \& Marupov, A. A. (2019). Main ways to improve the efficiency of agricultural land use in the Fergana valley sample. Scientific Bulletin of Namangan State University, 1(8), 68-74. 